\title{
Multiple Buddhisms in Ladakh: Strategic Secularities and Missionaries Fighting Decline
}

\author{
Elizabeth Williams-Oerberg ${ }^{1}$, Brooke Schedneck ${ }^{2, *}$ and Ann Gleig ${ }^{3}$ \\ 1 Department of Cross-Cultural and Regional Studies, University of Copenhagen, DK-2300 Copenhagen, \\ Denmark; elizawill@gmail.com or elizabeth.oerberg@hum.ku.dk \\ 2 Department of Religious Studies, Rhodes College, Memphis, TN 38112, USA \\ 3 Center for Religion and Civic Culture, University of Central Florida, Orlando, FL 32816, USA; \\ ann.gleig@ucf.edu \\ * Correspondence: schedneckb@rhodes.edu
}

check for updates

Citation: Williams-Oerberg,

Elizabeth, Brooke Schedneck, and Ann Gleig. 2021. Multiple Buddhisms in Ladakh: Strategic Secularities and Missionaries Fighting Decline. Religions 12: 932. https://doi.org/ $10.3390 /$ rel12110932

Academic Editor: Hiroko Kawanami

Received: 14 June 2021

Accepted: 20 October 2021

Published: 27 October 2021

Publisher's Note: MDPI stays neutral with regard to jurisdictional claims in published maps and institutional affiliations.

Copyright: (c) 2021 by the authors. Licensee MDPI, Basel, Switzerland. This article is an open access article distributed under the terms and conditions of the Creative Commons Attribution (CC BY) license (https:// creativecommons.org/licenses/by/ $4.0 /)$.

\begin{abstract}
During fieldwork in Ladakh in July-August 2018, three authors from Asian studies, anthropology, and religious studies backgrounds researched "multiple Buddhisms" in Ladakh, India. Two case studies are presented: a Buddhist monastery festival by the Drikung Kagyü Tibetan Buddhist sect, and a Theravada monastic complex, called Mahabodhi International Meditation Center (MIMC). Through the transnational contexts of both of these case studies, we argue that Buddhist leaders adapt their teachings to appeal to specific audiences with the underlying goal of preserving the tradition. The Buddhist monastery festival engages with both the scientific and the magical or mystical elements of Buddhism for two very different European audiences. At MIMC, a secular spirituality mixes with Buddhism for international tourists on a meditation retreat. Finally, at MIMC, Thai Buddhist monks learn how to fight the decline of Buddhism through missionizing Theravada Buddhism in this land dominated by Mahayana and Vajrayana Buddhism. Paying attention to this multiplicity-to "multiple Buddhisms" - we argue, makes space for the complicated, ambiguous, and at times contradictory manner in which Buddhism is positioned in regards to secularism and secularity.
\end{abstract}

Keywords: secularism; Buddhism; Ladakh; meditation; mindfulness; missionaries; monasticism; Vajrayana Buddhism; Theravada Buddhism

\section{Ethnographic Snapshots}

At a large Himalayan Buddhist festival in the Northwest Indian region of Ladakh, an Italian Buddhist monk asked the Buddhist master, Chetsang Rinpoche, why it was that terms such as "magical" and "mystical" have become more frequent in recent Mahayana Buddhist teachings, since, according to him, these terms have no place in Buddhist thought. Chetsang Rinpoche in his response sidestepped the question entirely by emphasizing the importance of studying the teachings and following a teacher. Later, when asked the same question, a younger Drikung Kagyü teacher responded matter-of-factly, "We tell them what they want to hear".

Statements such as "meditation is universal and scientific", and "you don't have to be a Buddhist to meditate" have become staple rhetoric as mindfulness meditation has moved into the secular spheres of medicine, education, and business. Yet these phrases were pronounced not by a therapist, educator, or business coach but by Bhikkhu Sanghasena, a Ladakhi Theravada Buddhist monk at his Mahabodhi International Meditation Center (MIMC) on the opening evening of a retreat for a global English-speaking audience.

Thai Theravada Buddhist monks who chose to spend the summer months at the MIMC in 2018 expressed that they are "just a small cog in a big wheel", hoping to help establish a Thai temple in Ladakh and extend the life of Buddhism past the 5000 year mark. Every action that this group of a dozen Thai monks had taken in Ladakh, they claimed, 
was with the aim of preventing the impending threat of secularism, hence stretching the life of Buddhism.

\section{Introduction}

Whether highlighting the supernatural aspects or the scientific aspects of Buddhist practice, the above examples show how Buddhist leaders adapt their teachings to appeal to specific audiences with the underlying goal of preserving the tradition. In the Himalayan Buddhist region of Ladakh, India, these varying discourses to promote Buddhism have become particularly evident. The extreme ends of a supernatural vs. secular-scientific continuum, of understanding Buddhism as a primarily "magical" and "mystical" religion or as a religion with correlations to science and a secular ethics, even as "not a religion", can be seen starkly in Ladakh, the traditionally Mahayana/Vajrayana Buddhist region in Northwest India. Distinct and multiple ways for how Buddhism is defined in relation to secularism are readily observed in this single location. Furthermore, the various ways in which Buddhism is understood and presented can be found not only in the same place among various strands of Buddhism, but also by the same Buddhist leaders depending on context and who is listening. Paying attention to this multiplicity - to "multiple Buddhisms" —we argue, makes space for the complicated, ambiguous, and at times contradictory manner in which Buddhism is positioned within conditions of secularism and secularity.

The simultaneous performance of the religious and secular, traditional and modern, particular and universal in Ladakh disrupts binary assumptions or oppositional tensions often undergirding debates about Buddhist modernism and the secularization of Buddhism in Western contexts (Thanissaro 2012; Borup 2013; Purser and Cooper 2014). Much scholarly ink has been spilt, for instance, on the relationship between the secular mindfulness movement and Buddhism (McMahan and Braun 2017; Wilson 2014). Many commentators have emphasized the difference and threat that secular mindfulness poses to "traditional" Buddhism (Thanissaro 2012; Purser 2015). Both advocates and critics of secular mindfulness and secular Buddhism in the West have commonly relied on an essentialist and binary framework that assumes the objectivity and stability of the categories of the religious and secular and places them in an oppositional relationship. As Jeff Wilson (2014, p. 9) notes, however, "Religion is not a phenomenon that exists neutrally in the world-it is a label applied variously by different people and by the same people at different times. This is true of its alleged opposite "the secular" as well ... [These terms] are markers of value employed strategically by agents in ways that reveal further patterns of value and preference". Ira Helderman (2019) extends Wilson's insight in his nuanced examination of how the categories of religion and secularism are strategically employed by Buddhist psychotherapists.

In a very different context from Buddhist-inspired North American therapy, we analyze the multiplicity of positions between Buddhism, modernization, and secularization as they take place on the ground in Ladakh. In doing so, we highlight both the production and reception of "multiple Buddhisms", showing how they operate on rhetorical, ritual, and aesthetic levels. We illuminate how the utilization of "strategic secularism" operates as a key feature of these multiple Buddhisms in Ladakh. Anthropologist Matthew Engelke (2009) developed the concept of strategic secularism to explain the processes by which religious agents incorporate secular formations into their agendas in the context of Bible advocacy work in England and Wales. We extend strategic secularism here to identify the ways in which Buddhist leaders strategically adopt secular discourses such as framing mindfulness meditation as universal and scientific, in large part motivated by a missionizing effort, which we will see is rooted in the desire to impede the decline of Buddhism. At the same time, we demonstrate that not all Buddhist leaders have the same capacity to be strategic. Depending on their background and opportunities for support, some monastics are able to tap into strategically secular discourses, while others remain unfamiliar with this option. Finally, we analyze how multiple Buddhisms and strategic secularism in Ladakh contribute to ongoing theoretical debates around modernism and secularism 
in contemporary global Buddhism. We argue that when deployed strategically, secular discourses are meant to aid in broadening sources of support. Not simply modernizing the tradition, secularism is used opportunistically to draw in as many adherents and maintain as many networks as possible.

Methodologically, this paper draws on participant-observation, qualitative interviews, and analysis of primary material undertaken in July-August 2018 in Ladakh, as part of a research project funded by the American Academy of Religion. We undertook collaborative research as three scholars of Buddhist studies with varying sub-fields of expertise, including anthropology, religious studies, and Asian Studies. Our collaborative interdisciplinary approach enabled us to expand and think across the boundaries of our own research populations, namely Ladakhi monastic and lay Buddhists, Thai missionary monastics, and an international group of Buddhist meditation inspired tourists. As we will show, being able to place our individual case studies in conversation enabled us to see a more complicated relationship between traditional Buddhism and secularity than would have been apparent from one context alone.

\section{Buddhism in Ladakh Background}

Situated in the Northwest Himalayan region of India, Ladakh is a high-altitude cold desert region bordering both Pakistan and China. During the summer of 2018 at the time of our research project, Ladakh was an autonomous district as part of the Jammu and Kashmir state. Ladakh is most often associated with Himalayan Buddhism, yet a large population of Muslims also lives in Ladakh. Ladakh is divided into two districts: Leh district with a Buddhist majority, and Kargil district with a Muslim majority. Because of the attraction of Buddhism, most of the tourism activity takes place in the Leh district, which is also where our research took place: in and around Leh town at various monasteries and one meditation center. Ladakh has often been referred to as "Little Tibet" due to the close relations with Tibet since the 8th century (Williams-Oerberg 2020a). Ladakhi Buddhist monks travelled to Tibet to pursue a monastic education, bringing home with them cultural influences from Tibet. Ladakh was an important station along central Asian trading routes, and a locus for economic as well as social and cultural exchange.

In 1974 when Ladakh was opened up for tourism, a few hundred, mostly European, tourists came to visit this bastion of Himalayan Buddhism. Ladakh lay along the so-called Himalayan hippie trail, attracting tourists who were interested in Asian spirituality and eventually ended their travels in Kathmandu (see Liechty 2017). The interest in travelling to Ladakh in search of spirituality and learning more about Himalayan Buddhism has only grown since 1974. Tourism is the largest industry in Leh, Ladakh and typically sees growth every year. Not every tourist visits Ladakh for the sake of religion and spirituality, of course. Even among those who primarily come for other reasons-such as the landscape, adventure tourism, even for Bollywood (a hugely popular film, 3 Idiots, was filmed there in 2009) - they invariably describe Ladakh as a calm and peaceful place, and as an ancient or medieval society, compared to other places in India (see Williams-Oerberg 2020a). Buddhist tourism has become an economic staple of Ladakhi society, with thousands, sometimes hundreds of thousands of tourists visiting the larger Buddhist monasteries during the busy summer months. Buddhist monasteries have welcomed the arrival of these tourists, advertising their monasteries and monastery festivals in tourism websites and magazines up to a year beforehand. The monastery festival, or tsé chu, is an annual Buddhist festival held in the courtyard of the larger monasteries in Ladakh at which time the cham or mask dance is performed in front of tourists and Ladakhis alike.

The impact that tourism has had in Ladakh is tremendous, most significantly through the economic resources brought into the region through these visiting tourists. Ladakh has witnessed swift economic as well as social and cultural changes since the 1970s when the tourism industry began to flourish. Heightened modernization processes have accompanied these changes in which long-standing social and cultural structures have been challenged. New employment opportunities through the tourism industry, as well as an 
expanding bureaucracy and military since Ladakh became part of post-colonial India, have become sources of social prestige, challenging entrenched social hierarchies which placed the royal family, the aristocracy, and most importantly, Buddhist monastics at the pinnacle. Improvements in the education sector, most specifically the introduction and spread of so-called "modern education", have introduced new understandings and lifestyles, further challenging the standing of monastic institutions in Ladakh. For example, in Ladakh, monasteries have played an important role in taking care of the religious landscape, which impacts every aspect of social and cultural life. Beliefs in what we can consider supernatural beings drove much of Ladakhi social life in which Ladakhi households were dependent on monastics to help take care of these beings and ensure that calamity through environmental disasters and sickness would be avoided. However, fewer Ladakhis attest to their beliefs in supernatural beings-referring to these practices as "superstition" and practiced out of "blind faith" (see Singh 2020; Williams-Oerberg 2017b).

In this way, we can recognize processes of secularization taking place in which monasteries have begun to lose their high standing in the social and cultural spheres, and become increasingly relegated to a cordoned-off religious monastic sphere. Here we draw on Casanova's (2011) discussion of "secular", "secularization", and "secularism". "Secular" refers to a modern epistemic category which is separated from the realm of the religious. However, as Casanova succinctly points out "it should be obvious that 'the religious' and 'the secular' are always everywhere mutually constituted" (p. 54). "Secularization" on the other hand, refers to a process of differentiation in which the various institutional spheres become distinct from one another, i.e., social, cultural, political, aesthetic, etc. "Secularism" refers to modern secular worldviews and ideologies. Although secularity is often defined as the absence of religion, it is by no means a neutral term (Calhoun et al. 2011, p. 5; Casanova 2011, p. 55). Religion becomes relegated to a traditional sphere, standing in opposition to modernity, and relies on "irrational" beliefs in magic and superstition (Casanova 2011). Within the context of post-colonial India, secularism has taken on a slightly different meaning beyond the absence or decline of religion, and instead emphasizes the equal treatment of all religions in India (see Calhoun et al. 2011; van der Veer 2002; Gayley and Willock 2016). This has had particular importance in modern education institutions, as "moral education", which in the past was based on religious ethics, can no longer draw upon religion and religion cannot be taught in school (Arvind 2011).

Buddhist monastic institutions in Ladakh have encountered processes of secularization and lost considerable influence in the wider society. In many ways, they have become cordoned off to a "religious" sphere and separated from the public social, cultural, and political spheres. Where monasteries were once at the center of social, political, and economic life in Ladakh (Mills 2001), today they struggle to maintain their positions of prestige. The primary task of monastics is to engage in Buddhist ritual, which has reduced in importance in the past few decades due to a rise in prioritizing science and scientific knowledge over superstitious belief. Narratives of Buddhist decline have become widespread throughout Ladakh, in which monastics, as well as social and political leaders bemoan the direction in which modernization processes and overall "development" have taken place (Williams-Oerberg Forthcoming).

Efforts in Ladakh to align Buddhism with trends similar to what has been recognized as modern Buddhism (McMahan 2008; Lopez 2002) have been underway since at least the 1930s (see Bertelsen 1997) with a more recent intensification following the demographic trend of an increasingly higher-educated population. Since this time, Ladakhi Buddhists have emphasized rational and reason-based understandings and practices of Buddhism, as well as an alignment with science and secularity (Singh 2020; Williams-Oerberg 2017b). This is similar to efforts throughout the Himalayas among Buddhist leaders to counteract the negative portrayal of Buddhists as "superstitious", "irrational", and "prehistoric" (see Pitkin 2016; Gayley and Willock 2016). Where Buddhist masters might have displayed "magical" powers previously, today there seems to be a distancing and reframing of these aspects into "wonders" and "marvels" (Fiordalis 2010, p. 382; see also Pitkin 2016; Robin 
2016). In this sense, the "spiritual" or the "magical" in Buddhism has become a "site of conceptual unease" (Bubandt and Beek 2012, p. 4). Efforts to introduce scientific subjects into the Buddhist monastic curriculum, as well as Tibetan Buddhist dialectics into the secular education curriculum as a form of Buddhist science, attest to this trend of Buddhist modernism in Ladakh. However, when looking more closely, this trend is often advocated by a particular sect of Himalayan Buddhists—the Geluk. The Dalai Lama, a renowned Geluk master, advocates for the inclusion of "secular ethics" in school curricula (Williams-Oerberg Forthcoming). Within an increasingly Buddhist sectarian environment in Ladakh, among other Himalayan Buddhist sects such as the Drikung Kagyü and Drukpa Kagyü, an alternative emphasis on the importance of tantric practice over academic study has been pronounced (see also DiValerio 2015). Whereas Buddhist modernist movements have often disregarded the "magical" and "mystical" as less grounded in Buddhist philosophy and more to do with blind faith and superstition, an alternative discourse emphasizing the supernatural instead of the secular or scientific aspects plays into debates as to which "Buddhism" is more applicable in the modern world. Bhikkhu Sanghasena, in establishing the Theravada Buddhist institute of the Mahabodhi International Meditation Center (MIMC), promotes his vision of a modern Buddhism, which is not only more secular-scientific, but also particularly aligned with what has been termed Socially Engaged Buddhism.

In the next stage of the paper, we present two case studies in Ladakh that highlight the complex, multiple ways in which Buddhism becomes aligned with the supernatural and with the secular-scientific, followed by further analysis. One case study focuses on a Himalayan Buddhist monastery festival in Ladakh, conducted by Williams-Oerberg. The second case study focuses on the Mahabodhi International Meditation Center, where Gleig and Schedneck engaged in research among both Thai monastics and international "spiritual" tourists. Both case studies show the production and performance of "multiple Buddhisms" in these sites with a simultaneous emphasis on the religious and secular, traditional and modern, particular and universal, depending on the specific audience the tradition is presented to.

\section{Case Study One: Buddhist Monastery Festival}

During July 2018, Williams-Oerberg attended a new Buddhist monastery festival at Tserkarmo monastery, located three hours outside of Leh town near Tingmosgang village. The festival commemorated the 800+ years since Lord Jigten Sumgön (b. 1143-1217), the founder of the Drikung Kagyü Himalayan Buddhist lineage, passed into parinirvana (Skt. parinirvāna). The 800+ commemoration of Lord Jigten Sumgön's parinirvana was attended by more than eight thousand people, including over 20 Rinpoches, more than 300 ordained monks and nuns, around 200 foreigners, and thousands of Ladakhis. ${ }^{1}$ Konchog Tenzin Thinley Lhundup (b. 1946) or the Drikung Kyabgön Chetsang Rinpoche, the 37th throne holder of the Drikung Kagyü lineage, presided over the festivities. Throughout the six days of the festival, Chetsang Rinpoche and the 13th Nubpa Tulku Konchok Tenzin Rinpoche (b. 1942) gave tantric transmissions and empowerments along with teachings on Buddhist philosophy. While a similar commemoration was previously held in the Indian town of Dehra Dun, the celebration in Ladakh also marked the inauguration of the newly built Tserkarmo monastery.

This Drikung Kagyü festival commemorated not only the history and founding of the lineage, but also its expansion across the globe. Since 1987, the exiled Tibetan leader Chetsang Rinpoche has worked to rebuild the Drikung Kagyü lineage in India and he began travelling across the world to give teachings attracting new followers. ${ }^{2}$ There are now Drikung Kagyü centers in 80+ countries across the globe, with new centers established every year. The globality of the Drikung Kagyü lineage was apparent at the 800+ commemoration of Lord Jigten Sumgön, drawing participants from all over the world, with more than 30 countries represented during the six days of the festival. 
On the first day of the festival, Chetsang Rinpoche invited the international participants to a question/answer session, at which time stark differences in approaches to Buddhism became apparent. It was here that the Italian Buddhist monk asked Chetsang Rinpoche in English why it was that terms such as "magical" and "mystical" have come up in recent explanations and teachings among Drikung Kagyü Buddhists. Williams-Oerberg had encountered what the Italian monk was referring to in their conversations with a group of Siberian and Russian-German women who had travelled the long distance to Ladakh to attend this $800+$ commemoration. These women did not self-identify as Buddhist, but they were on a self-recognized pilgrimage to Ladakh to learn more about the "ancient wisdom" and "mysticism" of Tibetan Buddhism from the Drikung Kagyü Buddhist leaders present at the festival. ${ }^{3}$ These Russian women identified first as healers and clairvoyants, and second as Orthodox Christians. Buddhism, especially Himalayan Buddhism, was primarily a resource to tap into in order to improve their healing practices and advance their spiritual path.

Having lived in Europe for over twenty years, Williams-Oerberg understood why this Italian tulku questioned the emphasis on magic and mysticism and on the supernatural in Drikung Kagyü Buddhism. Drikung Kagyü teachers have spent a lot of time in Europe during the past decade teaching Buddhist philosophy to interested Europeans. One Drikung Kagyü khenpo, or monastic teacher, was a visiting professor at the University of Copenhagen for one year, teaching Tibetan language and Buddhist philosophy. During a conversation with Hannah, ${ }^{4}$ a German woman who helped to establish one of the first Drikung Kagyü centers in Germany in the 1980s, she lamented about the Russians' interpretation of Buddhism as "spiritual" and "mystical". Hannah proclaimed: "The German Russians don't belong to any of our centers because they like to practice the Buddha Dharma in their own way, unfortunately", referring to their emphasis on adopting a bricolage of healing practices, of which Tibetan Buddhism offers one of many resources. The ways in which these interested Russians approach Buddhism, as a resource for tapping into mystical healing practices, however, have not led them to be excluded from Drikung Kagyü Buddhist institutions and teachers, quite the contrary. Although they do not selfidentify as Buddhist, they organize events in Germany and Siberia where they invite Drikung Kagyü masters to teach about the ancient wisdom of Buddhism, funding their travels along the way. During the $800+$ commemoration festival, these women participated diligently, listening carefully to the teachings, and receiving the Vajrayana empowerments, while also sitting in meditation during the breaks.

Later when Williams-Oerberg spoke with Lama Dawa ${ }^{5}$, one of the Ladakhi organizers of the 800+ commemoration who has spent a lot of time in Germany as a resident monk at a Drikung Kagyü center, she asked him about the question that the Italian tulku had posed, and why Chetsang Rinpoche did not directly address his question. Lama Dawa explained that if some people want to understand Tibetan Buddhism as magical and mystical, that is fine, even though there is no magic or mysticism in Tibetan Buddhism. "Actually, there is no word for mystical in Tibetan" he underlined. He then commented matter-of-factly, "We tell them what they want to hear"; thus bringing attention to the role audience plays in the multiple ways that Buddhism is being defined and how the secular is strategically positioned in contemporary Ladakh.

Throughout research in Ladakh during the past ten years, Williams-Oerberg has noticed consistent tropes of the supernatural vs. secular-scientific in the ways in which Buddhism is promoted in this historically Himalayan Buddhist region: Ladakhi Buddhist leaders promote Buddhism based on the varieties of audience, employing the common Buddhist pedagogical technique of upaya, skillful means. Having followed recent developments in Buddhism closely over this period, Williams-Oerberg has recognized distinct and multiple ways for how Buddhism is defined and how the secular is evoked, depending on which aspects of Buddhist thought and practice are highlighted. The emphasis often sways from the importance of Buddhist ritual for pacifying supernatural beings to how Buddhism is a science and philosophy, not a religion. In this sense, multiple Buddhisms 
can be found not only in the same place among various strands of Buddhism, but also by the same Buddhist leaders depending on context and who is listening.

\section{Case Study Two: Mahabodhi International Meditation Center (MIMC)}

In Williams-Oerberg's essay on "Socially-Engaged Sangha Economics in Leh, Ladakh", Williams-Oerberg (2017a), she profiles MIMC and its founder, the Theravada Ladakhi monastic: Bhikkhu Sanghasena (b. 1958-). She notes that in his role as a prominent socially engaged Buddhist leader in Ladakh, Sanghasena is an "outsider to dominant Ladakhi Buddhists and much more a part of the global network of Asian Buddhist modernists". In promotional material and in first-person discussions with him, Sanghasena traces his journey from Ladakhi soldier to monastic to socially engaged Buddhist. He shares that when he was a soldier, he had a powerful insight in which he realized that as a Buddhist, he should not be using guns. He decided to leave the army and seek monastic ordination. As Williams-Oerberg (2020b) explains, however, given that he was in his twenties and well past the age when young boys enter monasteries in Ladakh, he had difficulties finding a monastery that would accept him. This led him outside of Ladakhi Buddhism to the Theravada tradition where he joined the Maha Bodhi Center in Bangalore under the guidance of its founder, Theravada monastic Acharya Buddharakkhita. Since Buddharakkhita's death in 2013, Sanghasena is seen as leading the effort to reform and revitalize Buddhism in India. In the early 1990s, funded through an international network of sponsors, Sanghasena transformed a desert area about 30 min outside of Leh into the MIMC, which Williams-Oerberg (2017a) aptly describes as a "philanthropic empire". Framed with the mantra, "Compassion in action. Meditation in action", MIMC includes a school for the underprivileged, an old-age home, a home for the blind, a hospital, as well as a nunnery and monastery. MIMC participates in a number of pan-Asian Buddhist initiatives, including supporting the Thai monastics in their efforts to halt the decline of Buddhism and a Buddhist Youth Program which is explained on MIMC's website as "another initiative of Ven. Bhikkhu Sanghasena's aim at revitalizing Buddhism in its birthplace, India".

\subsection{Mahabodhi Retreat for English Speakers}

In addition to its philanthropic work, MIMC also hosts regular English language meditation retreats for tourists during the summer season, which was the focus of Gleig's research in Ladakh. Plastered across Leh were fliers advertising the retreats, which employed a mixture of Buddhist and secular rhetoric. One flier contained no words associated specifically with Buddhism but featured images of Buddhist nuns. Another signaled the "spiritual" and displayed the monastic Bhikkhu Sanghasena sitting near a stupa under Tibetan prayer flags but also omitted any Buddhist-specific language. When Gleig arrived for participant observation at the site, she was struck by the same co-mingling of particular religious and universal spiritual expressions. For instance, registration for the retreat took place in the bookstore, which contained a mix of Buddhist and New Age texts. One could labor over Pali, learn about enlightenment from the Dalai Lama, or leapfrog the spiritual ladder and get rich.

The retreat took place in a temple room with an altar and a striking gold Buddha statue. In the first evening session, Sister $\mathrm{Namgyal}^{6}$, who alternates teaching sessions with Sanghasena, asked male participants to sit on the left and female on the right and asked both to avoid pointing their feet towards the altar, both of which are common practices in Buddhist temples. She explained, however, that the mantra Om Mani Padme Hum would be playing on audio before Sanghasena entered the room but it was "just an expression of compassion" and to "just enjoy the sound of it". She also informed the participants that Guru-ji, which is how she referred to Sanghasena, would ask for the blessings of the Buddha, the Dharma, and the Sangha when he entered the room and encouraged everyone not to get into "internal reactivity" about it. 
The next morning, there was the first session with Sanghasena. He bowed, lit incense, and chanted Pali in front of the Buddha statue before turning to everyone and explaining "We start with reverence and seeking blessings from the Enlightened Ones for liberation and freedom from suffering". Next, he instructed that the participants would start the day by taking refuge in the Five Precepts in Pali. Despite starting with these specific Buddhist actions, Sanghasena moved quickly into rhetoric common to secular mindfulness, popularized by popular mindfulness teachers such as Jon Kabat-Zinn (1994) and Sam Harris (2015). First, Sanghasena decoupled the Buddha from Buddhism. As he implored: "Please do not make the Buddha, a Buddhist, Christ a Christian, Allah a Muslim. These are all enlightened Masters". Second, he distinguished between the external and the essential: "Many people recite prayers and mantras but do not know why-become a Buddha not a Buddhist". Third, he simultaneously placed meditation at the core of Buddhism and decoupled it: "Meditation is at the heart of Buddha's teachings, but it doesn't mean it just belongs to Buddhists". Fourth, he emphasized the compatibility of meditation with science, as he explained: "Meditation is universal and scientific". Finally, he positioned all the participants as potential renunciants dissatisfied with the empty pleasures of the material world. As he put it, "The fact that you came to Ladakh, to this meditation center, shows that you are seeking something-you are searching for satisfaction, for true happiness, you are not satisfied with the world of Coca-Cola" - "Coca-Cola" being used here as a euphemism for samsara.

An analysis of Sanghasena's speech shows a clear reproduction of the type of naturalization and universalization of Buddhism common to the multiple iterations of secular mindfulness, a rhetorical decontextualization that has drawn the ire of traditional and engaged Buddhist critics alike. He appears to have identified some of what Buddhist teachers like Chetsang Rinpoche and Lama Dawa have concluded non-Buddhists want to hear, but has not fully committed to these modern, secular discourses. Indeed, what is unusual in this case, is that the move from the religious/particular to the spiritual/universal is articulated through traditional Buddhist authority — the male monastic — and embedded within a ritualized, if somewhat eclectic, Buddhist site. The center is teeming with Buddhist stupas, statues, and paintings and these were directly incorporated into the retreat. For instance, one session involved a silent meditative walk to the stupa which everyone circumambulated around, chanting mantras before ending at Milarepa's caves where Sanghasena delivered a lengthy teaching on Milarepa's life and works.

Similarly, while Sanghasena promotes secular spirituality to attract non-Buddhist international retreatants, he also critiqued the ways in which Ladakh is becoming more secularized and losing the specific traditions of Buddhism. As the second part of this case study shows, MIMC annually hosts a group of Thai Buddhist monastics whose aim is to promote the visibility of Buddhism and strengthen monastic and lay relationships as part of a wider agenda to keep secularism at bay and halt the decline of Buddhism. A group of these Thai monastics were present at the site during the retreat. All the retreatants saw them returning from their alms round as well as meditating in the mountains. In addition to these male Theravada monastics, Ladakhi nuns from MIMC's nunnery joined the retreat to lead chanting at the evening session and support the participants during their mini-pilgrimage to the top of the mountain.

As Gleig pondered this simultaneous affirmation and disavowal of Buddhism, she was curious as to what the fellow retreatants were making of it. After the retreat, Gleig interviewed eight of the nineteen participants. Interviewees consisted of five women and three men, with an age range of 19-43 from Spain, France, Australia, Israel, and Canada. None identified as Buddhists but there was a mix of religious and secular identities: one identified as Catholic, one as Jewish, one as "spiritual but not religious", one as a cultural but not religious Jew, one as a non-practicing Christian, and three as neither spiritual nor religious. All eight identified meditation as the primary reason for attending the retreat, with one adding that they wanted to have the "full Ladakhi experience" and another sharing that they were looking for something "meaningful" in their life. 
Strikingly, seven of the eight identified Sanghasena's distinction between the Buddha and Buddhism as fundamental to them feeling comfortable at the retreat. As these individual responses show, such a distinction was important because it made the retreat less religious and more inclusive. Given the emphasis placed on this distinction, Gleig expected that participants might express some apprehension towards the Buddhist elements of the retreat such as the bowing and Pali chanting. In fact, the opposite was true: interviewees expressed both interest in and appreciation for the Buddhist components. Only one retreatant appeared to have struggled with the Buddhist aspects. During a tea party with Sanghasena, after the retreat, she shared that she had had a crisis after the first teaching session because of how Buddhist the space and teaching were. She felt this conflicted with her Jewish religious commitments and was planning to leave the retreat, but Sister Namgyal had visited her and convinced her that the retreat was not Buddhism and instead was part of the secular domain, so not in conflict with Judaism.

Apart from this experience, there were no other critiques raised about possible tensions between Buddhist elements and non-Buddhist rhetoric of the retreat. One retreatant did identify a contradiction: Sanghasena drew positive comparisons between science and Buddhism through linking the figures of Einstein and the Buddha, and then critiqued science and materialism the following day. The main critique raised by retreatants was directed at Sanghasena's rhetoric of "affirmative orientalism", in which he positioned the materialist West as needing the spiritual wisdom of the East. Retreatants felt that Sanghasena made too many generalizations about the East as spiritual and the West as materialist. Three of the interviewees brought up his use of Coca-Cola as a synonym for materialism and the nature of samsara. As Tara from Australia told Gleig, "I don't even like Coca-Cola!" Sanghasena's mixed Buddhist and strategic secular discourses seemed to work well for these participants, but not his simple generalizations concerning the modern world.

To supplement their small sample of qualitative material, Gleig analyzed the preand post-retreat forms that MIMC administers to retreatants. Containing reports from 156 participants ranging in gender, age, and nationality, Gleig identified four major categories for attending the retreat: (1) personal growth; (2) meditation practice; (3) learn about Buddhism; and (4) experience the natural beauty of the site. Similarly, Gleig identifies three major impacts of the retreat: (1) experiential: here the emphasis is on an extraordinary experience; (2) transformation: here the emphasis is on the impact of the experience with increased interest in Buddhism; and (3) aesthetic: here the emphasis is on the beauty of place (temple) and space (the Himalayas). In short, preliminary research on retreatants suggests in the main that they effortlessly access "multiple Buddhisms" and "non-Buddhisms" at MIMC. Similar to how Williams-Oerberg has shown that Ladakhi Buddhist leaders tell visitors "what they want to hear", Gleig found that retreatants hear what they want to hear at MIMC.

\subsection{Thai Buddhist Monks at MIMC}

Bhikkhu Sanghasena, in addition to reaching out to foreign tourists who visit Ladakh, also reaches out to Theravada Buddhists across Asia. He maintains key relationships with Thailand, through multiple nodes, including the Royal Thai Temple in Bodh Gaya, Wat Dhammakaya (the largest and most controversial temple in Thailand), a Thai spiritual master who brings a group of 30-40 people to workshops hosted by MIMC every year, ${ }^{7}$ and Thai socially engaged Buddhists Sulak Sivaraksa and Mae Chee Sansanee. ${ }^{8}$ Because of this attention from Thai Buddhist personalities, a project organizing a Buddhist pilgrimage in India contacted Bhikkhu Sanghasena.

In 2016 an annual pilgrimage for peace between Dharamsala to Leh, Ladakh, while stopping in Bodh Gaya, was established by the Thai Buddhist group called "Project for the Development of India, the Heir to the Land of the Buddha". ${ }^{9}$ The project already had an exchange with Thai temples in Dharamsala and Bodh Gaya, and wanted to extend this to Ladakh, even planning to build a Thai temple there. Two hundred Thai Buddhists 
participated in the 2018 pilgrimage, which ended at MIMC. ${ }^{10}$ The fourth year of this annual pilgrimage and rains retreat in Ladakh occurred in 2019 with 200 Thai monks participating in a three-day World Peace Conference held at MIMC. ${ }^{11}$ Each year, the pilgrimage group follows the same route, a distance of $847 \mathrm{~km}$ from Dharamsala to Leh, Ladakh. They begin by flying to Kolkata and traveling to Bodh Gaya. From there, they partake in a two-day bus tour to Varanasi, Delhi, and Dharamsala to begin the walking pilgrimage part of their journey. The group stays in Dharamsala for ten days training their bodies for the rigorous walk, receiving tents and medicines from the Dalai Lama. Bhikkhu Sanghasena emphasized that in all the years of the pilgrimage, not one participant has gotten sick, attributing this to the power of the dhamma. The Thai Buddhist monks from the 2019 group stated in an interview for The Times of India, that the one-month journey helped them to learn Buddhist teachings such as acceptance of suffering and impermanence. ${ }^{12}$ The pilgrimage ending in Ladakh is an important part of Sanghasena's connection with Thailand. This relationship is maintained through Thai monk pilgrims who spend three months in the center during their rains retreat.

Out of the eighty Thai Buddhist monks that undertook this pilgrimage in 2018, thirteen monks stayed behind to spread Buddhism in Ladakh. ${ }^{13}$ In July 2018, Schedneck interviewed these monks, observed their evening chanting ritual, and participated in their morning alms round. Schedneck discussed with the monks their goals and motivations for participating in this unique experience. After returning home, Schedneck kept in touch with two of the monks on Facebook and followed their social media posts through October 2018, when they returned to Thailand.

These monks came from all four regions of Thailand. Some of them heard about the project, which emerged out of Wat Pa Noun in Singburi province, because they also went on a Sri Lankan pilgrimage with the group in 2017. Others learned from the previous group of monks who came to Ladakh in 2017 that this was a good place to practice and develop their meditation in a peaceful environment. Because of this, most of them did not know each other beforehand but asserted that they had all become friends. They ranged in monastic years from one to twenty, with most of them averaging between three and nine years. The monks follow a similar monastic schedule to Thailand but have more time to practice because there is less activity in Ladakh for them than in Thai temples. When Schedneck arrived in August, the thirteen monks had been there for almost a month on their own, after the larger group had left. Some of the members of the larger pilgrimage group kept in touch with these monks, expressing their concern over whether they would have enough food or be warm enough when the season changed. ${ }^{14}$

These Thai Buddhist monks considered their role in Ladakh as missionaries of Theravada and Thai Buddhism. ${ }^{15}$ One of the monks, Phra Wit, now an abbot in a temple in the northeast region of Thailand, stated:

It is only Mahayana here and we are Theravada. Bhikkhu Sanghasena is the only Theravada monk here with one other Theravada monk, he has no one to help him spread Buddhism. We have come to show the people about Theravada and Thai Buddhism. There is no pindapat [alms round] here, so we show them. We go to market and some people gave at first but now more and more and they [the Ladakhi people] are learning through body language. Some invite us to come to their house. We can speak a little English to them, like "no money".

Although they could not speak Ladakhi, they found it important to show Thai Buddhism to the surrounding community of MIMC. They did this mainly through the daily alms round. They walked every morning from 8 a.m. to 9:30 a.m. The monks recounted that the 2016 group walked on alms round but never received anything and in 2017, the monks had a layperson to cook for them, so they did not enact the daily ritual. However, this 2018 group felt like they were spreading Buddhism during their morning ritual contact with the Ladakhi people. One morning in August, Schedneck followed the monks on this ritual, taking pictures, and helping them carry the food they collected. They walked and 
said "Julley" (hello in Ladakhi) to everyone they passed. Most people said "Julley" back and seemed to be used to them after their month staying in MIMC. The monks said in English, "no money, only something to eat", because part of their practice in Ladakh is to only receive food. Although monks conducting alms round in Thailand do not speak, they adjusted their typical protocol for this new environment. After one Ladakhi woman, who had at first tried to offer money, bought some food at the nearby store, Schedneck, having participated in many alms rounds in Thailand and encouraged by the Thai monks, facilitated the ritual for her, indicating how to kneel down and receive the blessing from the monks. Another Ladakhi woman invited the monks to her house and offered them fruit, tea, and cookies. When they chanted the blessing, she cried and appeared very moved. The monks were happy that they could bring the experience of the alms round to the Ladakhi people and stated that this was their main way of showing Buddhism.

However, during their stay, these Thai Buddhist monks noted a change from focusing exclusively on spreading Theravada Buddhist rituals in Ladakh to developing new strategies for spreading Buddhism in Thailand. They observed thousands of people who came to see the Dalai Lama during his visit to Ladakh and lamented that in Thailand these numbers would be much lower. Because of this, they felt that Theravada and Mahayana monks could work together to fight what they perceive to be an impending decline of Buddhism in Asia. In this way, it is not Himalayan Mahayana Buddhism that is seen as a threat to these Thai Buddhists, but the increasing secularity of Thailand, where Buddhism is perceived to be losing influence over society. ${ }^{16}$ Through this aim of tackling decline, these multiple Buddhisms of Ladakhi Theravada, Thai Theravada, and Mahayana Buddhism are able to find common purpose. Although they observed differences between Himalayan Buddhism and Theravada, such as stricter rules for monks in Thailand regarding their robes and touching women, when they went to listen to the Dalai Lama during his visit to Ladakh, they respected his influence, and wished Thai people had more faith and interest in Buddhism. As Phra Sek, a young monk, ordained for one year, explained:

"Mahayana tries for the Bodhisattva ideal while we try for nibbana. So, our end goal is different. Theravada is the foundation. The Mahayana is closer to the laity and in Theravada there is more difference [between the two groups]. There were so many people who came to listen to the Dalai Lama-thousands of people. In Thailand at most you could get would be 300-400. The Dalai Lama, broadly speaking, does good for society. Theravada and Mahayana should exchange more and we should learn how to get lots of people to listen like that. It was like they were coming for entertainment-whole families came. In Thailand only that many people would come for a concert. They [the Ladakhi people] respect him a lot and no one has to force them".

Phra Sek continued that he wants to help build the faith in Buddhism, noting that we are past the halfway point of the Buddha's dispensation and he is concerned about decline ${ }^{17}$ These kinds of reflections were the benefit of their extended period in Ladakh. They thought of their rains retreat in Ladakh as a chance to build and plant seeds of faith for the Ladakhi community and Thai Buddhist laity upon their return home. In fact, they were so concerned with missionizing, they asked me my opinion about how they can spread Buddhism most effectively. Throughout our interactions the Thai monks treated me as a knowledgeable Thai Buddhist because I spoke in Thai to them and described my previous research. They referred to me as yom, the Thai monastic label for a lay Buddhist.

However, the possibility of merit-making through the presence of the Thai monks was enough to fulfill their mission for the 2018 rains retreat. The fact that they could stay at MIMC and continue to be supported was a testament to the faith in Buddhism they perceived. During their alms round, they often did not receive enough food, but felt that they let "the Buddhist people here see Theravada Buddhism, so that faith in the Buddha and the Buddhist tradition would continue". Through their sacrifice of walking for about eight kilometers in the heat or cold and over thorns, they were carrying on the traditions of Thai Theravada monks and thus propagating Buddhism in this land. Just practicing proper 
monasticism and showing lay people was enough for their missionary work. They stated that they were not discouraged, even when receiving a little in the first month, because by the second month the Ladakhi lay people knew how to give alms and receive blessings. They hoped that in the future Thai tourists to Ladakh would know that there are Thai monks and a Theravada temple. The monks stated that right now there are a lot of Thai people who come, but the project must continue for them to be able to visit MIMC and make merit while traveling.

Phra Sek, the youngest monk, posted about his experiences of Ladakh on Facebook. In the first two months, he posted every day about the food offerings they received from Ladakhi and Thai supporters. During several days, Ladakhi lay people, who are patrons of MIMC, learned of the Thai monks and made large food offerings, purchasing from the nearby market. This made Phra Sek and the other monks so happy and surprised, their eyes welled up. Secondly, almost every day the Thai monks would receive donations from Thailand in their bank account. They would use this money to drive to the market and get food and drinks for themselves, along with extra donations they would offer to the school children, elderly, and disabled people living at MIMC. Instead of an in-person blessing after an offering, which is typical in Thailand, Phra Sek posted a picture of the person donating, the amount received in their bank account, the supplies the monks were able to buy, with a standard blessing in the post's text wishing health, wealth, and happiness to the merit-maker.

A project the monks were involved with during the month of September was building a meditation hut or kuti in the Thai style. This kuti was a major project and effort for the Thai monks, which they helped to build and which was fully funded through donations from Thailand (totaling THB 100,000 or about USD 3300), so that the future generations of this pilgrimage project will have a place to practice and to mark this land even further as a peaceful place of Buddhism. They left behind the kuti as well as an audio recording of their chanting that they gave to Bhikkhu Sanghasena and the children in the MIMC school. In his posts, Phra Sek is moved by the "land of Buddhism" in Ladakh as well as the generosity and concern of Ladakhi Buddhists. One of the experiences he highlights is meditating on the mountaintop. Phra Sek paints the scene, describing the stream they pass on the way as so clear and cool, flowing down from the Himalayas, which had the "scent of the dhamma and Buddha". Phra Sek was amazed that he could meditate in the negative temperature air, which was the first time for him and the other monks. Most of all he was impressed with "the tranquility, solitude, and sense of natural snow-covered beauty all around". In this way, Phra Sek kept members of the Thai Buddhist sangha updated on the group's activities in Ladakh, and this can inspire more donations. Phra Sek himself was inspired by the faith of the lay Thai Buddhists and felt that it was even more important to practice diligently in return. While Ladakhi Buddhist leaders, as part of Vajrayana communities, tell their international audience what they want to hear and English-speaking retreatants at MIMC take away what they want to experience, the Thai Buddhist monks believe that their performance of Thai Theravada monasticism will bring whoever they come into contact with closer to Buddhism and further away from a secular lifestyle. Because of their limited experience and lack of diverse audiences, they were not able to tap into the strategic kinds of secularism and multiple Buddhisms which Williams-Oerberg found among Ladakhi Vajrayana teachers and Gleig found in Bhikkhu Sanghasena, a Ladakhi Theravada teacher.

\section{Strategic Secularism and Multiple Buddhisms across Contexts}

In the case studies above, we see that some monastic leaders were able to tap into multiple Buddhisms - accessing different elements of Buddhism for different audiences. They created varying strategies to stretch the religion for increased appeal to non-Buddhists. Not just rationalizing the tradition as a kind of modern Buddhism, these monks also draw on the mystical, ritual, and even exotic aspects of Buddhism. These multiple Buddhisms require monks to discriminate between audiences, integrating secular discourses strategically. These ideas of strategic secularism and multiple Buddhisms are analyzed below, 
connecting our case studies with related previous scholarship. Our contribution is to articulate the motivation for and application of strategic secularity along with the necessity of multiple Buddhisms in a place like Ladakh, where monasteries rely on support from diverse audiences.

Following Bruntz and Schedneck (2020, p. 10), we are not reifying the binary between secular and religion but pointing "to the ways Buddhists use these categories to understand and demarcate what is internal and external to the tradition". At the same time that Buddhists might perceive secular forces, such as materialism and entertainment, to be an external threat, they are also interested in creating an alliance with secular forces, such as science and rationalism. When they compromise with secular forces, "they are doing so in order to expand networks of travelers, maintain financial viability, and educate people about Buddhist traditions" (p. 10). In this way, the religion's value seeps into and expands to include secular spheres.

How do monastic leaders act strategically using secularism? What makes some monks expert adapters and others not? This adaptation to new audiences is not just a contemporary phenomenon. Historian of religion Anne Blackburn (2010) found that the Sinhalese monk Hikkaduve Sumangala's influence of new colonial discourses work did not always supplant Buddhist ideas. During the colonial period in Ceylon, Sumangala and his monastic colleagues instead selectively added European forms of knowledge and expression to their writings as occasional ways to strengthen arguments. Buddhist educational interests, ritual, and monastic power remained important, and were not transformed based on the model of Protestant Christian practices. As Blackburn shows, Buddhist teachers and leaders have a history of strategically engaging with outside influences from the modern secular world.

Much of the work on contemporary Buddhist monks speaking in different registers, or codeswitching, among multiple audiences, has been done in diasporas. Monks living outside of their homeland are focused on getting support wherever they can, missionizing Buddhism, and expressing compassion and skillful means (upaya), because they believe Buddhist teachings can help reduce suffering. While Sumangala recognized the importance of Europe as an expression of modernity, the 14th Dalai Lama, as a refugee to India, sought support from the Western world by aligning Tibetan Buddhism with modern discourses. Michael Lempert (2012), in his work with Tibetan monastic educational institutions has highlighted how the Dalai Lama perpetuated this image as far back as the 1960s when, as a young, exiled refugee to India he began to fashion Tibetan Buddhism into a "modern" world religion. He sought to express its distinctiveness among world religions through its rational inquiry and compatibility with empirical science. For the Dalai Lama, scientists are of special concern because he seeks to portray Buddhism's legacy as having affinities with the European Enlightenment (Lempert 2012, p. 86). Perhaps, through these efforts, "the networks that connect exiled Tibetans with foreign scholars, supporters, and new Buddhist converts will result in sympathy, and from sympathy should come political and economic support, so that Tibet's fortunes will one day change" (ibid., p. 88). This focus on secular discourses is certainly strategic as it opens Buddhism to the Western world and garners support for Tibetan Buddhists. More recently, the Dalai Lama has been promoting what he terms as "secular ethics" as a morality not based in religion. The emphasis on compassion and interdependence, however, reveals clear roots in Buddhist ethics (see also Gayley and Willock 2016; Robin 2016; Williams-Oerberg Forthcoming). Bhikkhu Sanghasena, although not at the level of strategy and discourse as the Dalai Lama, is attempting to utilize the secular in similar ways. He both draws secularism into Buddhism, in the form of a rational meditation practice, and eschews it, arguing that the religious and spiritual values of Buddhism are better for world societies than the Western materialism he caricatures.

These strategic secularisms, which create multiple Buddhisms, are not only in dialogue with the West. Tibetan lamas in China also seek to meet the needs of their Chinese supporters. In Dan Smyer-Yü's (2020) research on the Tibetan Buddhist lama of Larung Gar Buddhist Academy, Khenpo Sodargye, who has been a successful teacher for non- 
Tibetan Han Chinese population, it was found that his teachings could be divided into two streams:

One is intra-Buddhist specific, regarding doctrinal teachings and methods of practicing discussed in Buddhist jargons. Another is his outreach to non-Buddhist audiences, addressing personally felt, systemic issues such as social morality, the pressures of the modern lifestyle, and environmental conservation, all in a modern, scientifically prone, vernacular lingo commonly accepted in Chinese society. The non-Buddhist world is thus the secular social field where Tibetan Buddhism finds sympathetic seekers, new converts, and opponents. (Smyer-Yü 2020, p. 49)

Other lamas he has observed within Tibetan Buddhism "emphasize the practical aspect of Tibetan Buddhism as they field inquiries about personal health, wealth, and future prospects from their Chinese followers" (ibid., p. 51). Similar to the Ladakhi monks studied by Williams-Oerberg, Khenpo Sodargye is ready to tell them what they want to hear. At the same time, these monastic teachers are not claiming that one of their code-switching registers is more real or authentic than another. All of these multiple Buddhisms are discussed as equal aspects of a diverse tradition.

Likewise, for many of the modern educated Ladakhi Buddhists Williams-Oerberg has met over the years, they have encountered Buddhism mostly through their interactions with tourists as well as through reading books in English which are geared towards an international, mostly non-Buddhist audience (see also Williams-Oerberg 2017b). For these modern-educated Ladakhi Buddhists, they were born Buddhist yet they "do not know Buddhism": they have not been given knowledge and understanding about the tenets of Buddhism and why Buddhist rituals are practiced. When driven by curiosity to know more about Buddhism, Ladakhis often consult English-medium sources, such as books, blogs, websites, etc., which mostly introduce various strands of Buddhist modernism (McMahan 2008). Through these sources, young Ladakhis come to understand Buddhist ritual practice as "superstition" and refer to the true meaning of Buddhism as a philosophy not a religion, as humanism and "secular ethics" (Williams-Oerberg Forthcoming).

For example, when Williams-Oerberg first met Lama Dawa a year before the 800+ commemoration, he explained to her how Buddhism is a spirituality and way of life. They met in Copenhagen while he was on a fundraising tour of Europe to establish a Buddhist orphanage. He was obviously used to speaking with Europeans and continued by explaining the meaning of religion: "religare", which means "to bind". He continued by mentioning how "Religion means binding your heart with your mind, the spiritual". ${ }^{18}$ Even though Dawa is a Buddhist monastic, having completed his Buddhist monastic education at the Kagyü College in Dehra Dun, he explained that he prefers to study about Buddhism in English-medium sources. Tibetan Buddhist texts, he explained, are very complicated and poetic, difficult to understand. "Westerners have read and understood these texts and written books which are much easier to understand", he explained. Perhaps Lama Dawa was telling Williams-Oerberg what he thought she "wanted to hear"? Or perhaps throughout the many years of interacting with Europeans and telling them "what they want to hear" he has incorporated these modern Buddhist understandings as his own and integrated them seamlessly with his Vajrayana Buddhist practice?

Part of the reason why there are these different Buddhisms for different communities is due to the ways Buddhism is perceived and imagined in Asian and non-Asian societies. Many Asian monastic teachers have helped to promote this image and continue to propagate the message of modern Buddhism while engaging in "religious" activities in their native languages. Teachers in Thailand's international meditation centers (Schedneck 2015, p. 125) "translate the retreat format from a standard Thai Buddhist program into a global one that resonates with a decontextualized religious practice" which includes psychological, universal, and secular imaginaries of Buddhism. The global nature of modern Buddhist discourses created the possibilities for these teachers to cater to imaginaries of Buddhism for non-Buddhist audiences. Through international meditators' feedback and reactions 
to the retreat, international meditation center teachers in Thailand learn to speak modern Buddhism and recognize the ways this audience understands Buddhism differently from their Thai Buddhist audience.

Monastic figures popular with non-Buddhists in North America and Europe must match their image to the cultural expectations of this audience. Richard Payne (2016) has compared the humble terms in which the Dalai Lama presents himself, resonating with American popular religion, with Yogi Chen, a monastic serving the immigrant Chinese community in San Francisco. Yogi Chen, on the opposite extreme, speaks in only one register, a self-aggrandizing style which is consistent with the expectations of his audience. Payne labels this as "consistent with the competitive nature of premodern Tibetan religious culture" (p. 34).

Buddhists have always adapted their message to new audiences and time periods as part of being a universal, missionary religion. We can see this in the case of Tibetan lamas with Chinese audiences and the Dalai Lama with the global English-speaking world, and in our examples from Ladakh, Bhikkhu Sanghasena and Drikung Chetsang Rinpoche. However, some monks do not adapt to all groups, like Yogi Chen for an international audience and the Thai monks in Ladakh who are not able to tailor their message, having not spent enough time to know different audiences.

\section{Conclusions}

As the preceding section shows, Buddhists across Asian and Western contexts have engaged in strategic secularity, which produces multiple Buddhisms tailored to meet the needs of different audiences, as part of a pragmatic response to preserving Buddhism in a secular world. Our case studies in Ladakh show how the secular is used to reinscribe ways of being religious, of enacting Buddhism. Buddhist monks are transforming the secular into something they can work with, integrate, critique, and eschew, accepting it into their repertoire of teaching for Buddhist and non-Buddhist audiences.

This comparison of multiple Buddhisms is striking for the fact that it is all happening in one place at the same time. In Ladakh, there are Ladakhi Theravada monks, Ladakhi Mahayana/Vajrayana monks, and Thai monks, who are facing similar problems and creating related solutions. Because of the three authors' differing expertise, we were able to pull these stories out of our ethnographic fieldwork period. Williams-Oerberg has deep relationships with Ladakhi monks, Gleig found that the international spiritual tourist population in Ladakh had resonances with their research in North American Buddhism, and Schedneck's knowledge of Thai Buddhism allowed them to investigate how monks with little familiarity with Ladakh navigated their rains retreat there. If there was only one author, we would have obtained only one of these stories. Yet, all of our cases fall under similar questions: How do Buddhist monks promote and make their religion appealing to multiple audiences? What are their strategies for fighting the decline of Buddhism? In what ways do they utilize the secular in their work to make Buddhism more present in the world?

For the Drikung Kagyü festival, transnational Buddhists from places such as North America and Europe often become introduced and attracted to Buddhism due to its secularscientific alignment. On the other hand, an emphasis on the magical and mystical is often valued by another cohort of transnational Buddhists-those from Russia and Eastern Europe. For an international audience who is more interested in the supernatural, these aspects of Himalayan Buddhism are highlighted. When Lama Dawa refers to Buddhism as a spirituality, he does so based on his familiarity with a European audience that often disparages religion and favors spirituality, and a Russian audience that is more keen to hear about "Eastern mysticism". Among this latter group, claims on the scientific values of Buddhist thought are less important than the magical and mystical aspects of Buddhism which are aligned with wider spiritual trends in Russia and Eastern Europe, such as clairvoyance, healing, numerology, cosmology, and other forms of spirituality often considered under the broader umbrella of new age spirituality. Hence, depending 
on the audience, Tibetan Buddhist leaders in Ladakh at times have catered to "what they want to hear", emphasizing alternatively the scientific or the supernatural, the secular or the religious. Rather than understanding these discrepancies as hypocrisy or merely paradoxical, this is part and parcel for how we can understand modern Buddhism in contemporary contexts.

Sanghasena's seamless code-switching between the universal and particular, religious and secular-spiritual, demonstrates a "strategic secularity" and reveals his primary values and preferences. First, his aim is certainly not to convert retreatants to Buddhism but rather to generate their economic support for his socially engaged Buddhist projects. In the tea party he hosted after the retreat, his efforts were clearly focused on generating financial support and international connections for these Buddhist-based philanthropic projects. In Schedneck's interview with him as well, Sanghasena was interested in the connections to various funding institutions she could provide.

In terms of the relationship of this strategic secularity to "traditional" Buddhism, the situation is complex. On the one hand, Sanghasena's engaged Buddhism rests on a critique of traditional Buddhism in Ladakh-which he labels as socially apathetic. On the other, however, it also resists forces of secularization that endanger traditional Ladakhi Buddhism. As Williams-Oerberg (2020b) shows, such socially engaged Buddhism serves to resist the wider processes of secularization underway in Ladakh through returning Buddhism to public spaces. Similarly, as the case study of Thai Buddhist monks in Ladakh has demonstrated, Sanghasena is a key figure in Asian Buddhist attempts to halt secularization and the decline of Buddhism in Thailand. Sanghasena strategically adopts secular rhetoric to support his engaged Buddhism, which in turn is revitalizing Asian Buddhism against the forces of secularity.

Bhikkhu Sanghasena, through his MIMC, tries to insert Theravada Buddhism into Ladakh, a traditionally Mahayana/Vajrayana Buddhist place, while Thai monks hope to maintain and expand Theravada monastic orthodoxy. These monks believe that what they can offer, the monastic traditions of Theravada Buddhism, will slow the infringement of secularism in Ladakh and Thailand. In contexts where multiple Buddhisms exist, not just national Buddhist competition but also comparison and a common goal to combat secularism can arise. When Buddhism is perceived to be losing its influence on a global scale, the case in Ladakh indicates that making Buddhism present in the world becomes a pressing concern.

In conclusion, such strategic secularity produces "multiple Buddhisms" that emerge in even the same Buddhist sites or through the same Buddhist leaders, which disrupt many of the prevailing binaries of the modern and traditional that too often frame and limit discussions of contemporary global Buddhism.

Author Contributions: All authors contributed equally to the conceptualization, methodology, formal analysis, investigation, resources, data curation, original draft preparation, review and editing, visualization, project administration, and funding acquisition. All authors have read and agreed to the published version of the manuscript.

Funding: This research received external funding from the American Academy of Religion.

Institutional Review Board Statement: Ethical review exempt due to use of pseudonyms and oral history interviews.

Informed Consent Statement: Informed consent was obtained from all subjects involved in the study.

Conflicts of Interest: The authors declare no conflict of interest.

\section{Notes}

One of the main organizers of the event offered these estimates during a personal interview, Leh.

http:/ / www.drikung.org/their-holiness/hh-kyabgoen-chetsang, accessed on 5 November 2019.

One of the Siberian women in the group acted as the leader and translator. During the conversations, this woman translated from Russian to English, and used the terms "mysticism" and "ancient wisdom" in her translations to English. 
Pseudonym. All of the non-public figures mentioned in this article are pseudonyms.

Again, pseudonym.

Sister Namgyal is a pseudonym used to provide anonymity.

Master Sathittham Pensuk, who calls himself "the universal channeling master" as well as a "New Age Spiritual Master", has two books written in English. These are titled Messages from the Universe and Jumping Evolution: The Spirituality of Success Getting New Rich. In the latter book he explains that he has a spiritual connection with the Himalayan region.

8 This information comes from an interview with Bhikkhu Sanghasena on 10 August 2018 at MIMC. He stated that he attends many international Buddhist conferences, and connects with many leaders there. He also receives awards from these Thai Buddhist leaders, and afterwards he invites them to Ladakh and they often come every year after their initial visit.

9 This is one of several projects between Thailand and India. The purpose of these missionary pilgrimages is to propagate Thai Buddhism within the land of Buddhist heritage. These pilgrimages often result in monks spending time in India, at least for the rains retreat. The experience is meant to create faith for these monks and subsequently in Buddhism by the Thai Buddhist laity. Most of these pilgrimages involve monks and lay people walking and traveling between the four sites of the Buddha's birth, enlightenment, preaching, and death. These are organized by various temples, organizations, and partnerships between India and Thailand. For example, see these two articles: https:/ /www.posttoday.com/life/healthy/569960 (accessed on 22 October 2021). https:/ / www.thairath.co.th/news/society/1517365 (accessed on 22 October 2021).

10 This is not the only group to go on pilgrimage, known as thudong in Thai, in India from Thailand. Another organization that sponsors this is called Thai-Dharamsala Charity Society. They walk from Dharamsala to Manali and end in Ladakh, starting in 2016. https:/ / tibet.net/2017/06/thai-monks-embark-on-their-peace-march-to-manali-after-receiving-blessings-from-his-ho liness / (accessed on 20 November 2019). A third group walking thudong to practice dhamma in India is a group of Thai monks from Pathalung walking to Chiang Rai for one month and a half. After this they fly to Nepal and walk into India, not receiving any money on the way-only water and food. This group of six monks appears to not be associated with any organization—but organized on their own as part of two temples in Patthalung: https:/ /hilight.kapook.com/view/180010?fbclid=IwAR2-d6VU5r zCTyvWg1QxVC52yw0I-7GL5PnZHVSefh7Be6KI3nVpM66uwBg (accessed on 22 October 2021).

11 Seema Sharma, “Leh's Bhikkhu Sanghasena honored with World Book of Records for promoting world peace along with 200 monks from Thailand" https://m.timesofindia.com/city/chandigarh/lehs-bhikkhu-sanghasena-honored-with-world-book-of-r ecords-for-promoting-world-peace-alongwith-200-monks-of-thailand/amp_articleshow/70044819.cms?utm_source=facebook. com\&utm_medium=social\&utm_campaign=TOIDesktop\&_twitter_impression=true\&fbclid=IwAR0SBXTHn9a7gcmCtxiu8iX cUw9y-7WMkIHEd88YQz1qziAaWzbD-DLwPCg (accessed on 22 October 2021).

Ibid.

13 Schedneck was able to interview these monks before their evening chanting session on August 11th. Six of the monks came to chanting that night. Schedneck met all thirteen on their alms round the next day. One of them had taken a vow of silence for the rainy season. In 2017, the group of monks that stayed in Ladakh for the rains retreat numbered eight.

14 One monk stated that he could not take any pictures of the food and send them to the laity because it would cause the laity to be sad. The monks could not obtain the ingredients to make proper Thai food. They walked to the market for alms round in the morning but drove there in the afternoons to get ingredients for cooking. They borrowed a small car from MIMC in order to purchase necessities. In Thailand, driving a car would be considered inappropriate for a monk. Similar to their adaptations to the alms round, the Thai monks were able to adapt to the needs of the situation in this new location for their monastic practice.

15 All of the Thai monastic names are pseudonyms.

16 Schedneck is using secular here as an analytic, etic term. The monks themselves used terms of spreading Buddhism and decline. The secular, as something separate from the temple and Buddhist education, was implied in their discussion of decline, citing people's increasing interest in non-Buddhist activities, such as entertainment and shopping.

17 Phra Sek is referring to the popular decline scheme of the Buddhist teachings lasting 5000 years after the Buddha's death. In 2019, we are about 2600 years past this point.

18 Recorded interview, Copenhagen, 9 May 2017.

\section{References}

Arvind, Gaysu R. 2011. Colonialism, Modernism, and Neo-Liberalism: Problematizing Education in India. In Handbook of Asian Education: A Cultural Perspective. Edited by Yong Zhao, Nagwa Megahed, Jing Lei, Kaori Okano, David Gamage, Hema Ramanathan, Ming Fang He and Guofang Li. London: Routledge, pp. 481-502.

Bertelsen, Kristoffer Brix. 1997. Early Modern Buddhism in Ladakh: On the Construction of Buddhist Ladakhi Identity, and Its Consequences. In Recent Research on Ladakh 7, Proceedings of the 7th Colluquium of the International Association for Ladakh Studies, Bonn/Sankt Augustin, Germany, 12-15 June 1995. Edited by Thierry Dodin and Heinz Räther. Bonn: Universitat Bonn, pp. 67-88. Blackburn, Anne. 2010. Locations of Buddhism: Colonialism and Modernity in Sri Lanka. Chicago: University of Chicago Press.

Borup, Jorn. 2013. Aloha Buddha-The Secularization of Ethnic Japanese-American Buddhism. Journal of Global Buddhism 14: $23-43$. 
Bruntz, Courtney, and Brooke Schedneck. 2020. Introduction: Theroretical Landscapes of Buddhist Tourism in Asia. In Buddhist Tourism in Asia. Edited by Courtney Bruntz and Brooke Schedneck. Honolulu: University of Hawaii Press, pp. 1-26.

Bubandt, Nils, and Martijn van Beek. 2012. Varieties of Secularism- in Asia and in Theory. In Varieties of Secularism in Asia: Anthropological Explorations of Religion, Politics, and the Spiritual. Edited by Nils Bubandt and Martijn van Beek. New York: Routledge, pp. 1-28.

Calhoun, Craig, Mark Juergensmeyer, and Jonathan VanAntwerpen. 2011. Introduction. In Rethinking Secularism. Edited by Craig Calhoun, Mark Juergensmeyer and Jonathan Van Antwerpen. Oxford and New York: Oxford University Press, pp. 3-30.

Casanova, José. 2011. The Secular, Secularitizations, Secularisms. In Rethinking Secularism. Edited by Craig Calhoun, Mark Juergensmeyer and Jonathan Van Antwerpen. New York: Oxford University Press, pp. 54-74.

DiValerio, David M. 2015. The Holy Madmen of Tibet. New York: Oxford University Press. [CrossRef]

Engelke, Matthew. 2009. Strategic Secularism: Bible Advocacy in Britain. Social Analysis 53: 39-54. [CrossRef]

Fiordalis, David V. 2010. Miracles in Indian Buddhist Narratives and Doctrine. Journal of the International Association of Buddhist Studies 33: 381-408.

Gayley, Holly, and Nicole Willock. 2016. Introduction: Theorizing the Secular in Tibetan Cultural Worlds. Himalaya 36: 12-21. Available online: https: / / digitalcommons.macalester.edu/himalaya/vol36/iss1/8 (accessed on 22 October 2021).

Harris, Sam. 2015. Waking Up a Guide to Spirituality Without Religion. New York: Simon and Schuster.

Helderman, Ira. 2019. Prescribing the Dharma: Psychotherapists, Buddhist Traditions, and Defining Religion. Chapel Hill: University of North Caroline Press.

Kabat-Zinn, Jon. 1994. Wherever You Go, There You Are: Mindfulness Meditation in Everyday Life. Boston: Hachette Books.

Lempert, Michael. 2012. Discipline \& Debate: The Language of Violence in a Tibetan Buddhist Monastery. Berkeley: University of California Press.

Liechty, Mark. 2017. Far Out: Countercultural Seekers and the Tourist Encounter in Nepal. Chicago: University of Chicago Press.

Lopez, Donald S., Jr., ed. 2002. A Modern Buddhist Bible: Essential Readings from East and West. Boston: Beacon Press.

McMahan, David L. 2008. The Making of Buddhist Modernism. New York: Oxford University Press.

McMahan, David L., and Erik Braun, eds. 2017. Meditation, Buddhism, and Science. Oxford and New York: Oxford University Press.

Mills, Martin A. 2001. Identity, Ritual and State in Tibetan Buddhism: The Foundations of Authority in Gelukpa Monasticism. Richmond: Curzon.

Payne, Richard. 2016. Self-Representation and Cultural Expectations: Yogi Chen and Religious Practices of Life-Writing. Entangled Religions: Interdisciplinary Journal for the Study of Religious Contact and Transfer 3: 33-82. [CrossRef]

Pitkin, Annabella C. 2016. The 'Age of Faith' and the 'Age of Knowledge': Secularism and Modern Tibetan Accounts of Yogic Power. Himalaya. 36, pp. 96-115. Available online: https://digitalcommons.macalester.edu/himalaya/vol36/iss1/13 (accessed on 22 October 2021).

Purser, Ronald, and Andrew Cooper. 2014. Mindfulness's Truthiness Problem: Sam Harris, Science and the Truth About Buddhist Tradition. Salon, December 6.

Purser, Ronald. 2015. Clearing the Muddled Path of Traditional and Contemporary Mindfulness: A Response to Monteiro, Musten and Compson. Mindfulness 6: 23-45. [CrossRef]

Robin, Françoise. 2016. Souls Gone in the Wind? Suspending Belief About Rebirth in Contemporary Artistic Works in the Tibetan World. Himalaya 36: 116-29. Available online: https://digitalcommons.macalester.edu/himalaya/vol36/iss1/14 (accessed on 22 October 2021).

Schedneck, Brooke. 2015. Thailand's International Meditation Centers: Tourism and the Global Commodification of Religious Practices. New York: Routledge.

Singh, Rohit. 2020. Authenticating Buddhism in the Public Sphere: Moral Dialogues in Ladakh. Journal of Global Buddhism 21: 171-86. [CrossRef]

Smyer-Yü, Dan. 2020. A Sino-Tibetan Buddhist Modernism: Religious Marketplace, Constellative Networking, and Urbanism. In Buddhism and Business: Merit, Material Wealth, and Morality in the Global Market Economy. Edited by Trine Brox and Elizabeth Williams-Oerberg. Honolulu: University of Hawaii Press, pp. 40-58.

Thanissaro, Bhikku. 2012. Right Mindfulness: Memory and Ardency on the Buddhist Path. Available online: https://www.accesstoin sight.org/lib/authors/thanissaro/rightmindfulness.pdf (accessed on 22 October 2021).

van der Veer, Peter. 2002. Religion in South Asia. Annual Review of Anthropology 31: 173-87. [CrossRef]

Williams-Oerberg, Elizabeth. 2017a. Socially-Engaged Sangha Economics in Leh, Ladakh. Paper presented at Sangha Economies: Temple Organisation and Exchanges in Contemporary Buddhism, Max Planck Institute of Social Anthropology, Halle/Saale, Germany, September 21-22.

Williams-Oerberg, Elizabeth. 2017b. Young Buddhism: Analyzing Transnational Currents of Religion among Ladakhi Buddhist Youth in India. In Eastspirit: Transnational Spirituality and Religious Circulation in East and West. Edited by Jørn Borup and Marianne Qvortrup Fibiger. Leiden and Boston: Brill, pp. 255-78.

Williams-Oerberg, Elizabeth. 2020a. Buddhism: A Unique Selling Proposition (USP) in Ladakh. In Buddhist Tourism in Asia. Edited by Courtney Bruntz and Brooke Schedneck. Honolulu: University of Hawai'i Press, pp. 227-46.

Williams-Oerberg, Elizabeth. 2020b. Buddhist Business and Benevolence in Leh, Ladakh. Journal of Human Values 27: 60-71. [CrossRef] 
Williams-Oerberg, Elizabeth. Young Buddhism: The Centrality of 'Youth' in Modern Buddhism and Contemporary Buddhist Movements. Journal of Global Buddhism. Forthcoming.

Wilson, Jeff. 2014. Mindful America: The Mutual Transformation of Buddhist Meditation and American Culture. Oxford and New York: Oxford University Press. 